\title{
Effect of Integrated Nutrient Management on Growth Parameters of Black Gram (Vigna mungo L.)
}

\author{
Vipul Beniwal ${ }^{1,2^{*}}$ and Ajay Tomer ${ }^{1}$ \\ ${ }^{1}$ Department of Agronomy, School of Agriculture, LPU, Phagwara, Punjab - 144411, India \\ ${ }^{2}$ ICAR-CICR, Regional Station, Sirsa, Haryana - 125055, India \\ *Corresponding author
}

\section{A B S T R A C T}

\begin{tabular}{|l|}
\hline Ke y w o r d s \\
Black gram, \\
$\begin{array}{l}\text { Growth, Nutrient, } \\
\text { Number of leaves }\end{array}$ \\
\hline Article Info \\
\hline $\begin{array}{l}\text { Accepted: } \\
\text { 15 May } 2019 \\
\text { Available Online: } \\
\text { 10 June } 2019\end{array}$ \\
\hline
\end{tabular}

\section{Introduction}

Black gram (Vigna mungo L.) $2 \mathrm{n}=24$ is a selfpollinated crop which grows up to 35 to 50 $\mathrm{cm}$ in height having yellow flowers with an auxiliary inflorescence, belongs to the family Fabaceae sub family Papilionaceae. It is distributed from different parts of Asia andit contains three times high percentage of quality protein than cereals, also rich in carbohydrate, fat, amino acids, vitamins and minerals. It is broadly used in various cuisine preparations. It is a soil nourishing crop. Which fixes nitrogen from the atmosphere through symbiotic nitrogen fixation. After the removal of pods, the green plants can be used

\section{removal of pods, the green plants can be used}

Effect of integrated nutrient management on growth parameters of black gram var. Mash 114 was conducted under field conditions, during (kharif) season of 2017. The research was conducted with nine treatments, in which one control, $100 \%$ recommended dose of fertilizer alone and seven treatments with combination of organic and inorganic fertilizers i.e. farm yard manure $5 \mathrm{t} \mathrm{ha}^{-1}$, vermi-compost $2.5 \mathrm{t} \mathrm{ha}^{-1}$ and poultry manure $2.5 \mathrm{tha}^{-1}$ and nitrogen $5 \mathrm{~kg} \mathrm{ha}^{-1}$ and phosphorus $11 \mathrm{~kg} \mathrm{ha}^{-1}$ respectively and Rhizobium along with biofertilizer as used for seed treatment. Observations were recorded on growth parameters such as plant height $(\mathrm{cm})$, number of leaves plant ${ }^{-1}$ and number of branches plant ${ }^{-1}$. An application of $100 \%$ recommended dose of fertilizer gave maximum plant height (51.37 $\mathrm{cm}$ ) at 85 DAS (days after sowing), number of leaves (26.60) plant $^{-1}$ and branches plant ${ }^{-1}$ 14.00 at $60 \mathrm{DAS}$ in treatment $\mathrm{T}_{1}$ as compared to others. 
tropics, sub-tropics and $1828 \mathrm{~m}$ above sea level (Singh et al., 2017). It is also called as mash in India (Kaewwongwal et al., 2015).

Black gram is the most important legume crop and India alone produce more than two-third of the world's production (Saini and Jaiwal, 2002) as food, feed and industrial raw material and ranks as the third important pulse crop in India (Selvakumar et al., 2012). Total black gram production was 3280 thousand tonnes; of which percentage share in $13.48 \%$ during 2017-18 (Anonymous, 2017-18). Due to its wider adaptability, it is grown across a wide range of agro-ecological zones. In Punjab, cultivation is about 1.1 million tons of mash every single year from about 2.2 thousand hectares of area with an average productivity of $539 \mathrm{~kg}$ per hectare (20152016). Black gram considered as a staple food for about 900 million consumers and about one third of all underfed children. After green revolution cereal grain production increased, which resulted in sharp decline of per capita production and availability of pulses with record of 4.0 million tonnes of imported pulses in 2012-13 (Singh et al., 2017).

The term pulse refers as the dried seed/grain. In India major pulse crops grown are chickpea, pigeonpea, mung bean, urd bean and lentil etc. These are highly nutritious, rich in dietary fiber, sugar and almost contains no fats (Kokani et al., 2014). In India a large portion of black gram is used in cooking dal makhani, dal bati, sweets, papad, snacks, idli, and curries, it comprises of all the major nutrients and can be eaten after sprouting of seeds by soaking it in water in fact the dried seeds are rich in phosphorus and nitrogen (of albumin and globulin), it is very rich in digestible protein contents involves proteins $26 \%$, carbohydrates $56-60 \%$, fat $1.5 \%$, oil $1.5 \%$, fiber $4.5 \%$ and phosphoric acid on the basis of dry weight consumed per capita globally. It holds ample amount of calorie contents 347 calories per 100 gm (Amruta et al., 2016). Furthermore, the nutrients management is one of the key elements that influence the growth and yield of black gram. It requires both macro and micro nutrients for their growth and development just as soybean (Nambiar and Abrol, 1992). Therefore, the important role of this research was to find out the effect of integrated nutrient management on growth parameters of black gram.

\section{Materials and Methods}

The research was conducted during the summer (kharif) season of 2017 at the Lovely Professional University, Phagwara, India. To study "Effect of integrated nutrient management on growth parameters of black gram (Vigna mungo L.)". The treatments comprised of three organic manure farm yard manure $5 \mathrm{t} \mathrm{ha}^{-1}$, vermi-compost and poultry Manure 2.5t $\mathrm{ha}^{-1}$. However, in-organic fertilizers are nitrogen $5 \mathrm{~kg} \mathrm{ha}^{-1}$ (urea@11 $\mathrm{kg} \mathrm{ha}^{-1}$ ) and phosphorus $11 \mathrm{~kg} \mathrm{ha}^{-1}$ (DAP @ $25 \mathrm{~kg} \mathrm{ha}^{-1}$ ) and bio-fertilizer Rhizobium used as seed treatment. The unit plot size was 15.9 $\mathrm{m}^{2}$. The trail was laid out in randomized complete block design (RCBD) replicated three times with nine treatments including control in sandy loam soil of Punjab, with slightly alkaline $\mathrm{pH}$ (7.6). The research was conducted at department of Agriculture, which is situated at $31.24^{\circ}$ North Latitude and $75.69^{\circ}$ East Latitude, with an average elevation and mean sea level of $252 \mathrm{~m}$, which falls under central plain zone of agro-climatic zones of Punjab. Mash 114 (released during 2008) is the black gram variety which is usually grown in kharif season under various cropping systems of Punjab. The plant growth habit is dwarf, erect and compact, up to a height of $60-65 \mathrm{~cm}$, podding is profuse and each pod contains about 6-7 seeds, which is bold and black. Crop duration of 80-85 days, variety with yielding ability up to 36.00 $\mathrm{q} \mathrm{ha}^{-1}$. 


\section{Treatments details}

The experiment consisted of (9) treatments combination involving organic manure and inorganic fertilizers. All the organic manure was applied as per treatments to each plot thirty-five (35) days before sowing of the crop. The details of treatments were given in Table 1.

The observations were recorded in terms of plant height $(\mathrm{cm})$, leaves number and branches number per plant at different time intervals after sowing. In black gram the height of plant from each plot was measured at 30 and 85 DAS (days after sowing), while the number of leaves and branches were measured at 30 and 60 DAS intervals.

The statistical data in which the treatment effects were significant, the appropriate standard error of mean and the critical difference $(\mathrm{CD})$ were analysed at $5 \%(\mathrm{p} \leq$ $0.05)$ level of significance using ' $F$ ' test. The mean value of the collected data from each plot was subjected to analysis of variance (ANOVA) and the data were analysed using SPSS statistical software. The experiment was laid out in randomized block design having nine treatments randomized in to three replications. The data generated during the course of the study was subjected to statistical analysis using OPSTAT software (Sheoran et al., 1998).

\section{Results and Discussion}

Present studies entitled "Effect of integrated nutrient management on growth parameters of black gram" were conducted under field conditions with the objective. The effect of integrated nutrient management on recommended dose of fertilizer, farm yard manure, vermi-compost and poultry manure on growth habits of black gram. Thus the results were depicted the following heads.

\section{Plant height (cm)}

Plant height of black gram was recorded at three different intervals (30,60 and 85 DAS) and the influence of organic and inorganic sources are depicted in Table 2 and Figure 1.

The plant height observations recorded at 30 , 60 and 85 DAS were significantly different among the treatments. The maximum plant height at 30 DAS was recorded in $\mathrm{T}_{1}(22.55$ $\mathrm{cm})$ followed by $\mathrm{T}_{4}(21.91 \mathrm{~cm}), \mathrm{T}_{3}(21.87$ $\mathrm{cm}), \mathrm{T}_{6}(20.66 \mathrm{~cm}), \mathrm{T}_{2}(19.38 \mathrm{~cm}), \mathrm{T}_{7}(18.79$ $\mathrm{cm})$ and $\mathrm{T}_{8}(18.77 \mathrm{~cm})$, while the minimum plant height was observed in $\mathrm{T}_{5}(18.30 \mathrm{~cm})$. At 60 DAS the maximum plant height was also recorded in $\mathrm{T}_{1}(34.47 \mathrm{~cm})$ which was statistically at par with $\mathrm{T}_{4}(33.27 \mathrm{~cm})$ and the minimum plant height was recorded in $\mathrm{T}_{0}$ $(25.13 \mathrm{~cm})$.

Similarly, the maximum plant height at the time of harvest (85 DAS) was recorded in $\mathrm{T}_{1}$ $(51.37 \mathrm{~cm})$ and the minimum height was recorded in $\mathrm{T}_{0}(43.87 \mathrm{~cm})$.

The maximum increased in plant height was observed in those plots treated with $100 \%$ $\mathrm{RDF}$ and $75 \% \mathrm{RDF}+25 \%$ vermi-compost. The possible reason for this could be because the growing pattern and increased seed rate that allows the plant to avoid inter plant competition for nutrients (Rathore et al., 2010). Sufficient amount of nutrients from the inorganic fertilizers as well as some from the organic fertilizers improves the cell activities, cell multiplication and luxuriant growth of the plant which could explained the increased in plant height of the crop (Fashina et al., 2002).

The reduction in the nitrogen at an early growing stage could reduce the rate of photosynthesis which could attribute in the reduction of plant height (Paul and Driscoll, 1997). Similar findings were also reported by Singh et al., (2011). 
Table.1 Treatments details

\begin{tabular}{|l|l|}
\hline $\mathbf{T}_{\mathbf{0}}$ & Control \\
\hline $\mathbf{T}_{\mathbf{1}}$ & 100\% RDF (Urea and DAP) \\
\hline $\mathbf{T}_{\mathbf{2}}$ & 75\% RDF + 25\% Farm yard manure \\
\hline $\mathbf{T}_{\mathbf{3}}$ & 50\% RDF + 50\% Vermi-compost + Rhizobium \\
\hline $\mathbf{T}_{\mathbf{4}}$ & 75\% RDF + 25\% Vermi-compost \\
\hline $\mathbf{T}_{\mathbf{5}}$ & $50 \% \mathrm{RDF}+50 \% \mathrm{FYM}+$ Rhizobium \\
\hline $\mathbf{T}_{\mathbf{6}}$ & 75\% RDF + 25\% Poultry Manure \\
\hline $\mathbf{T}_{\mathbf{7}}$ & 50\% RDF + 50\% Poultry manure + Rhizobium \\
\hline $\mathbf{T}_{\mathbf{8}}$ & 25\% RDF + 25\% PM + 25\% VC + 25\% FYM + Rhizobium \\
\hline
\end{tabular}

Where, RDF- Recommended dose of fertilizer (NPK), DAP- Diammonium phosphate, DAS- Days after sowing, FYM- Farm yard manure $\left(5 \mathrm{tha}^{-1}\right)$, PM- Poultry manure $\left(2.5 \mathrm{tha}^{-1}\right)$, VC- Vermi-compost $\left(2.5 \mathrm{tha}^{-1}\right)$, N-Nitrogen 5 $\mathrm{kg} \mathrm{ha}^{-1}$ (Urea@ $11 \mathrm{~kg} \mathrm{ha}^{-1}$ ), P- Phosphorus $11 \mathrm{~kg} \mathrm{ha}^{-1}$ (DAP @ $24 \mathrm{~kg} \mathrm{ha}^{-1}$ ), Rhizobium- $500 \mathrm{~g} \mathrm{ha}^{-1}$ (Seed treatment).

Table.2 Effect of integrated nutrient management on plant height (cm) at 30, 60 and 85 DAS

\begin{tabular}{|l|c|c|c|}
\hline Treatments $\mathbf{( T )}$ & 30 DAS & 60 DAS & 85 DAS \\
\hline $\mathbf{T}_{\mathbf{0}}$ & $17.34^{\mathrm{d}}$ & $25.13^{\mathrm{e}}$ & $43.87^{\mathrm{b}}$ \\
\hline $\mathbf{T}_{\mathbf{1}}$ & $22.55^{\mathrm{a}}$ & $34.47^{\mathrm{a}}$ & $51.37^{\mathrm{a}}$ \\
\hline $\mathbf{T}_{\mathbf{2}}$ & $19.38^{\mathrm{bcd}}$ & $29.67^{\mathrm{bc}}$ & $49.87^{\mathrm{a}}$ \\
\hline $\mathbf{T}_{\mathbf{3}}$ & $21.87^{\mathrm{ab}}$ & $30.13^{\mathrm{b}}$ & $50.79^{\mathrm{a}}$ \\
\hline $\mathbf{T}_{\mathbf{4}}$ & $21.91^{\mathrm{ab}}$ & $33.27^{\mathrm{a}}$ & $51.11^{\mathrm{a}}$ \\
\hline $\mathbf{T}_{\mathbf{5}}$ & $18.30^{\mathrm{cd}}$ & $27.13^{\mathrm{de}}$ & $47.78^{\mathrm{a}}$ \\
\hline $\mathbf{T}_{\mathbf{6}}$ & $20.66^{\mathrm{abc}}$ & $29.80^{\mathrm{bc}}$ & $50.64^{\mathrm{a}}$ \\
\hline $\mathbf{T}_{\mathbf{7}}$ & $18.79^{\mathrm{cd}}$ & $27.67^{\mathrm{cd}}$ & $49.71^{\mathrm{a}}$ \\
\hline $\mathbf{T}_{\mathbf{8}}$ & $18.77^{\mathrm{cd}}$ & $27.33^{\mathrm{de}}$ & $48.90^{\mathrm{a}}$ \\
\hline $\mathbf{S . E} \mathbf{~ m} \mathbf{( \pm )}$ & 0.867 & 0.754 & 1.092 \\
\hline $\mathbf{C D} @ \mathbf{5 \%}$ & 2.62 & 2.28 & 3.30 \\
\hline
\end{tabular}

Table.3 Effect of integrated nutrient management on number of leaves per plant at 30, 60 and 85 DAS

\begin{tabular}{|l|c|c|c|}
\hline Treatments (T) & 30 DAS & 60 DAS & 85 DAS \\
\hline $\mathbf{T}_{\mathbf{0}}$ & $9.53^{\mathrm{d}}$ & $21.73^{\mathrm{c}}$ & $18.10^{\mathrm{abcde}}$ \\
\hline $\mathbf{T}_{\mathbf{1}}$ & $11.53^{\mathrm{a}}$ & $26.60^{\mathrm{a}}$ & $18.73^{\mathrm{abc}}$ \\
\hline $\mathbf{T}_{\mathbf{2}}$ & $10.07^{\mathrm{cd}}$ & $23.53^{\mathrm{bc}}$ & $19.33^{\mathrm{a}}$ \\
\hline $\mathbf{T}_{\mathbf{3}}$ & $9.93^{\mathrm{cd}}$ & $23.67^{\mathrm{bc}}$ & $18.00^{\mathrm{bcde}}$ \\
\hline $\mathbf{T}_{\mathbf{4}}$ & $11.20^{\mathrm{ab}}$ & $26.60^{\mathrm{a}}$ & $17.00^{\mathrm{e}}$ \\
\hline $\mathbf{T}_{\mathbf{5}}$ & $9.93^{\mathrm{cd}}$ & $21.13^{\mathrm{c}}$ & $19.10^{\mathrm{ab}}$ \\
\hline $\mathbf{T}_{\mathbf{6}}$ & $10.93^{\mathrm{abc}}$ & $24.73^{\mathrm{ab}}$ & $18.33^{\mathrm{abcd}}$ \\
\hline $\mathbf{T}_{\mathbf{7}}$ & $10.33^{\mathrm{bcd}}$ & $23.07^{\mathrm{bc}}$ & $17.23^{\mathrm{de}}$ \\
\hline $\mathbf{T}_{\mathbf{8}}$ & $9.60^{\mathrm{d}}$ & $22.47^{\mathrm{bc}}$ & $17.53^{\text {cde }}$ \\
\hline $\mathbf{S . E} \mathbf{~ m} \mathbf{( \pm )}$ & 0.338 & 0.705 & 0.407 \\
\hline CD $@ \mathbf{5 \%}$ & 1.02 & 2.13 & 1.23 \\
\hline
\end{tabular}


Table.4 Effect of integrated nutrient management on number of branches per plant at 30 and 60 DAS

\begin{tabular}{|l|c|c|}
\hline Treatments (T) & 30 DAS & 60 DAS \\
\hline $\mathbf{T}_{\mathbf{0}}$ & $2.00^{\mathrm{c}}$ & $8.00^{\mathrm{c}}$ \\
\hline $\mathbf{T}_{\mathbf{1}}$ & $3.67^{\mathrm{a}}$ & $14.00^{\mathrm{a}}$ \\
\hline $\mathbf{T}_{\mathbf{2}}$ & $2.67^{\mathrm{abc}}$ & $11.00^{\mathrm{abc}}$ \\
\hline $\mathbf{T}_{\mathbf{3}}$ & $2.67^{\mathrm{abc}}$ & $10.67^{\mathrm{abc}}$ \\
\hline $\mathbf{T}_{\mathbf{4}}$ & $3.33^{\mathrm{ab}}$ & $13.67^{\mathrm{a}}$ \\
\hline $\mathbf{T}_{\mathbf{5}}$ & $2.33^{\mathrm{bc}}$ & $8.67^{\mathrm{c}}$ \\
\hline $\mathbf{T}_{\mathbf{6}}$ & $3.00^{\mathrm{abc}}$ & $13.33^{\mathrm{ab}}$ \\
\hline $\mathbf{T}_{\mathbf{7}}$ & $2.67^{\mathrm{abc}}$ & $9.67^{\mathrm{bc}}$ \\
\hline $\mathbf{T}_{\mathbf{8}}$ & $2.00^{\mathrm{c}}$ & $9.00^{\mathrm{c}}$ \\
\hline S.E $\mathbf{~} \mathbf{( \pm )}$ & 0.40 & 1.23 \\
\hline CD @ 5\% & $\mathrm{NS}$ & 3.72 \\
\hline
\end{tabular}

Fig.1 Impact of integrated nutrient management on plant height (cm) at 30, 60 and 85 DAS

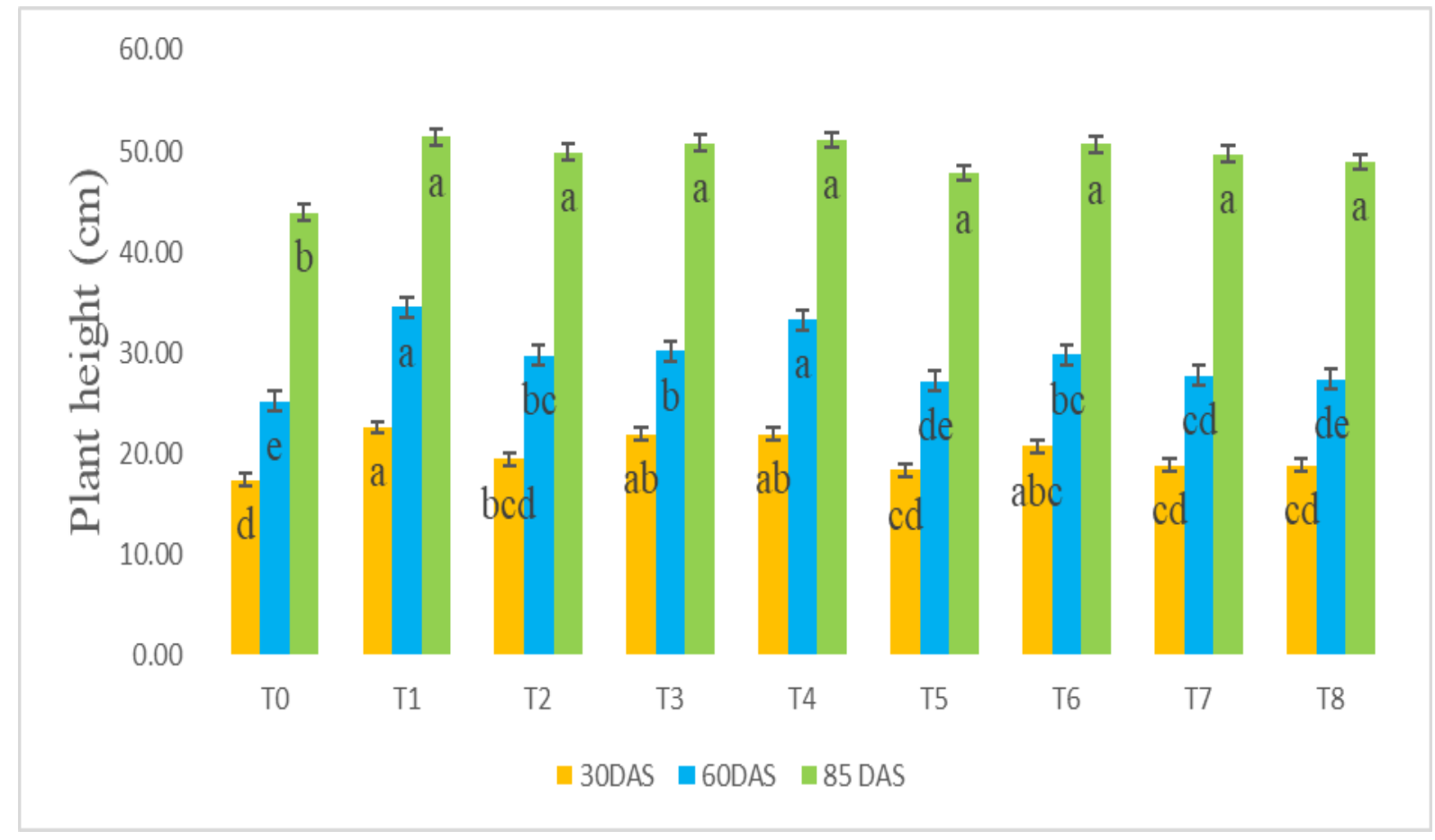


Fig.2 Impact of integrated nutrient management on number of leaves at 30, 60 and 85 DAS

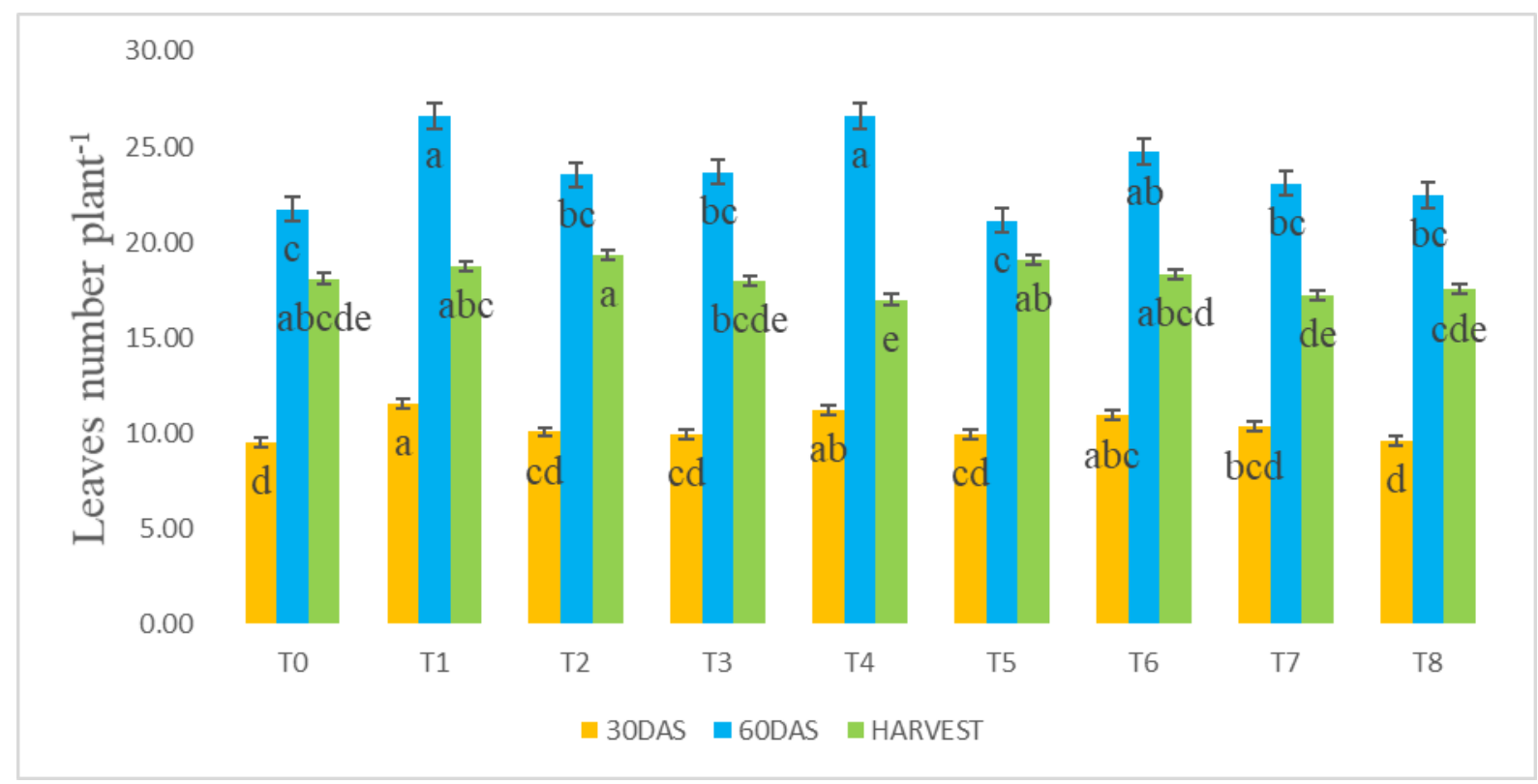

Fig.3 Impact of integrated nutrient management on number of branches per plant at 30 and 60 DAS

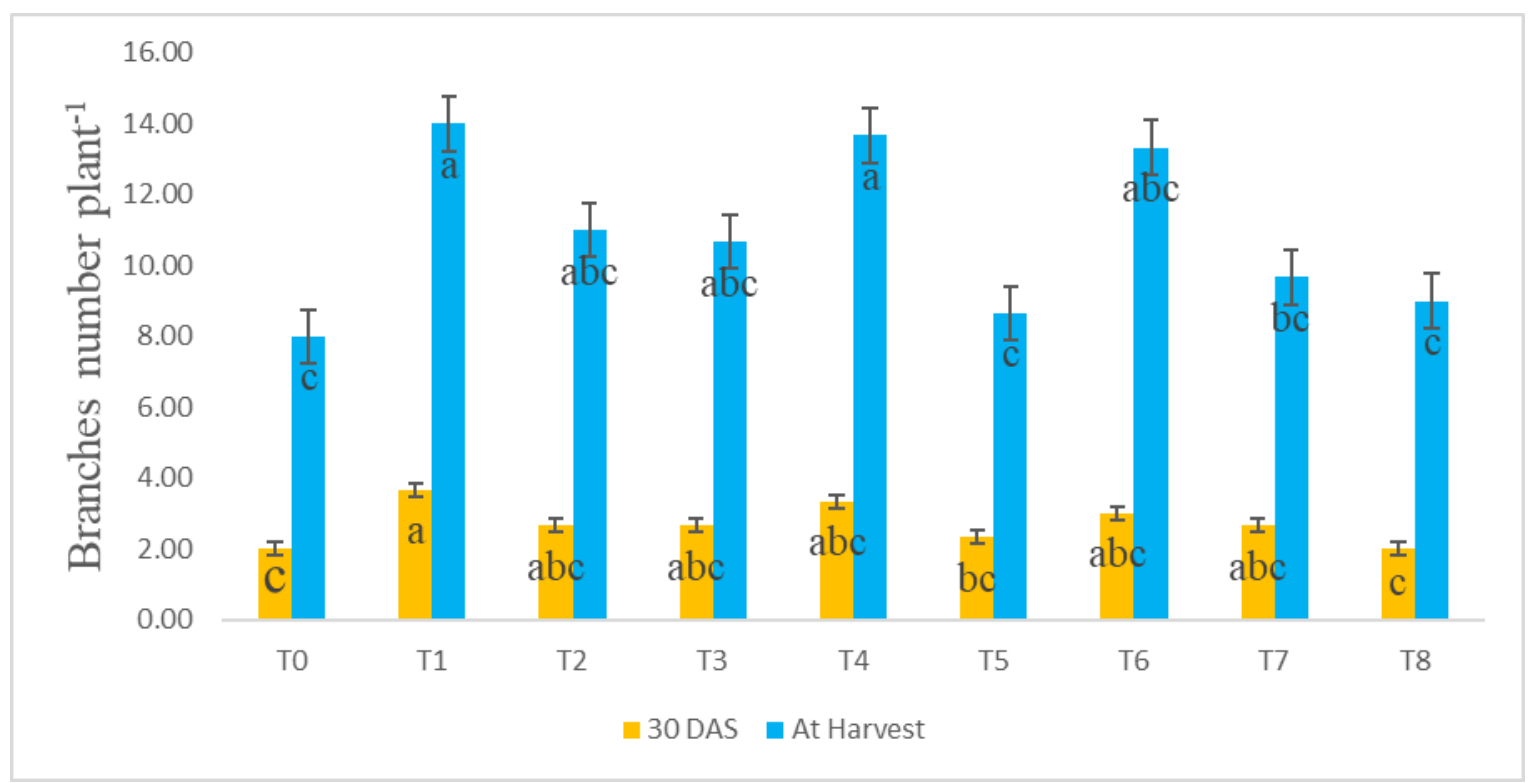

\section{Leaves number plant $^{-1}$}

The effect of integrated nutrient management on number of leaves of black gram were found to have no significant difference amongst the treatments at 30,60 and 85 DAS at the time of harvest (Table 3 and Figure 2).
At 30 DAS the maximum number of leaves were observed in $\mathrm{T}_{1}(11.53)$ followed by $\mathrm{T}_{4}$ (11.20). At 60 DAS the minimum number of leaves were recorded in $\mathrm{T}_{5}(21.13)$ which was lower by $\mathrm{T}_{1}$ (26.60) and $\mathrm{T}_{4}$ (26.60) which were the maximum number of leaves recorded. At the time of harvest (85 DAS), 
the maximum number of leaves were recorded in $T_{2}$ (19.33) which was higher than control $\mathrm{T}_{0}(17.00)$.

The increased in number of leaves per plant were either observed in plots treated with 100 $\%$ RDF or plots treated with combination of organic and inorganic fertilizers. Application of fertilizers solely or in combined form improves the soil fertility level as well as nutrients which enables better root development and root nodules allowing the plant to take up the nutrients with ease which might be the reason for increase in the number of leaves (Rathore et al., 2010). Similar finding was also reported by Vadgave (2010).

\section{Branches number plant ${ }^{-1}$}

The statistical analysis at an initial stage (30 DAS) revealed that number of branches per plant were found to have no significant difference (Table 4 and Figure 3) amongst the treatments but when comparisons were made $\mathrm{T}_{1}$ (3.67) and $\mathrm{T}_{4}$ (3.33) were higher than $\mathrm{T}_{0}$ (2.00) and $\mathrm{T}_{8}(2.00)$.

At 60 DAS the treatments were significantly different between all the treatments and the maximum numbers of branches were observed in $\mathrm{T}_{1}$ (14.00) followed by $\mathrm{T}_{4}(13.67)$ which were both higher than control i.e., $\mathrm{T}_{0}$ (8.00).

Reddy et al., (2011) reported that the increased in number of branches could be possible because the application of organic and inorganic fertilizers along with biofertilizers due to enhancement of microbial activity in the rhizosphere which enables the roots for the better uptake of nutrients. Similarly, the application of organic and inorganic fertilizers increases the overall growth attributes of the crop due to their synergistic effect Singh et al., (2008; 2011).
Summary and Conclusion is as follows:

The growth parameters of black gram i.e. plant height, leaves number plant ${ }^{-1}$, branches number plant ${ }^{-1}$ was significantly varied with different treatments. It was also reported that all growth parameters significantly increased with the increasing doses $100 \%$ with RDF. Amongst all the treatments $100 \%$ of RDF gave maximum plant growth as compared to other treatments at different growth intervals. While, it was at par with application of $75 \%$ $\mathrm{RDF}+25 \%$ vermi-compost.

It was also reported that during these studies the recommended dosage of fertilizer gave significantly higher in plant height $\left(\mathrm{T}_{1} 100 \%\right.$ RDF at harvest $34.47 \mathrm{~cm}$ ), leaves number plant $^{-1} 26.60$ at 60 DAS and branch number plant $^{-1} 14.00$ over control when compared to other treatments.

\section{Acknowledgement}

Necessary facilities and help during research activities provided by faculty of School of Agriculture, LPU, Rupinder Singh and Dr. Jagdeep Singh is highly acknowledged.

\section{References}

Amruta, N., Devaraju, P. J., Mangalagowri, S. P., Ranjitha, H. P. and Teli, K. 2016. Effect of integrated nutrient management and spacing on seed quality parameters of black gram cv. Lbg-625 (rashmi). Journal of Applied and Natural Science. 8(1): 340-345.

Anonymous, 2017-18. Directorate of Economics and Statistics (DES): Based on 3rd Advance Estimates for 2017-18. Commodity Profile for Pulses-July, 2018.

Fashina, A. S., Olatunji, K. A., and Alasiri, K. O. 2002. Effect of different plant populations and poultry manure on the 
yield of Ugu (Telfairia occidentalis) in Lagos State, Nigeria. In Proceedings of the Annual Conference of Horticultural Society of Nigeria (HORTSON), pp. 1417.

Fuller, D. Q. and Harvey, E. L. 2006. The archaeobotany of Indian pulses: identification, processing and evidence for cultivation. Environmental Archaeology. 11(2): 219-246.

Kaewwongwal, A., Kongjaimun, A., Somta, P., Chankaew, S., Yimram, T., and Srinives, P. 2015. Genetic diversity of the black gram [Vigna mungo (L.) Hepper] gene pool as revealed by SSR markers. Breeding Science. 65(2): 127137.

Kokani, J. M., Shah, K. A., Tandel, B. M. and Nayakan, P. 2014. Growth, yield attributes and yield of summer Black Gram (Vigna mungo L.) as influenced by FYM, phosphorus and sulphur. The Ecoscan. Special Issue. VI: 429-433.

Nambiar, K.K.M. and Abrol, I.P. 1992. Long term fertilizer experiments in India - An overview. Fertilizer News. 34(4): 11-26.

Paul, M. J., and Driscoll, S. P. 1997. Sugar repression of photosynthesis: the role of carbohydrates in signaling nitrogen deficiency through source: sink imbalance. Plant, cell \& environment. 20(1): 110-116.

Rathore, R. S., Singh, R. P., and Nawange, D. D. 2010. Effect of land configuration, seed rates and fertilizer doses on growth and yield of black gram [Vigna mungo (L.) Hepper]. Legume Research: An International Journal. 33(4): 274-278.

Reddy, A., Babu, J. S., Reddy, M., Khan, M., and Rao, M. M. 2011. Integrated nutrient management in pigeonpea (Cajanuscajana). International Journal of Applied Biology and Pharmaceutical Technology. 2(2): 467-470.

Saini, R., and Jaiwal, P. K. 2002. Age, position in mother seedling, orientation, and polarity of the epicotyl segments of blackgram (Vigna mungo L. Hepper) determines its morphogenic response. Plant Science. 163(1): 101-109.

Selvakumar, G., Reetha, S. and Thamizhiniyan, P. 2012. Response of biofertilizers on growth, yield attributes and associated protein profiling changes of blackgram (Vigna mungo L. Hepper). World Applied Sciences Journal. 16(10): 1368-1374.

Sheoran, O. P., D. S. Tonk, L. S. Kaushik, R. C. Hasija and R. S. Pannu1998. Statistical software package for Agricultural Research Workers. Recent Advances in information theory, Statistics and computer Application by D.S. Hooda and R.C. Hasija Department of Mathematics Statistics, CCS HAU, Hisar. 139-143.

Singh, G., Ram, H., Sekhon, H. S., Aggarwal, N., Kumar, M., Kaur, P., and Sarma, P. 2011. Effect of nitrogen and phosphorus application on productivity of summer mungbean sown after wheat. Journal of Food Legumes. 24(4): 327-329.

Singh, R. K., Dawson, J., and Srivastava, N. 2017. Effect of sources of nutrient on growth and yield of blackgram (Vigna mungo L.) Varieties in NEPZ of India. Journal of Pharmacognosy and Phytochemistry. 6(4): 1064-1066.

Singh, V. K., Sharma, B. B. and Sahu, J. P. 2008. Effect of organic and inorganic sources of nutrients on black gram productivity. Journal of Food Legumes. 21(3): 173-174.

Tateishi, Y. 1996. Systematics of the species of vigna subgenus ceratotropis. Mungbean germplasm: collection, evaluation and utilization for breeding program. Japan International Research Center for Agricultural Sciences, pp. 924.

Vadgave, S. M. 2010. Studies on Integrated Nutrient Management on Seed Yield, 
Quality and Storability in Greengram [Vigna radiate (L.) Wilczek] (Doctoral dissertation, UAS, Dharwad). immunity and breeding of cultivated plants: selected writings of NI Vavilov. Chronica Botanica. 72(6): 482.

Vavilov, N. I. 1951. The origin, variation,

\section{How to cite this article:}

Vipul Beniwal and Ajay Tomer. 2019. Effect of Integrated Nutrient Management on Growth Parameters of Black Gram (Vigna mungo L.). Int.J.Curr.Microbiol.App.Sci. 8(06): 2045-2053. doi: https://doi.org/10.20546/ijcmas.2019.806.244 